\title{
O NASCIMENTO DA LITERATURA DO ESPÍRITO DA FICÇÃO: UM ESTUDO SOBRE AS RELAÇÕES ENTRE OS CONCEITOS DE FICÇÃO E OS DE LITERATURA
}

\begin{abstract}
Resumo: O ensaio pretende investigar as relações entre os conceitos de ficção e os de literatura, partindo da hipótese de que somente após os homens reconhecerem algo como sendo da ordem do ficcional - isto é, somente depois que o entendimento humano concebe a ocorrência de fenômenos cuja característica essencial é a de situarem-se entre os domínios do real e do falso - faz sentido pensar numa circunscrição específica dos discursos que chamamos, modernamente, de Literatura. Para tanto, dividiu-se o artigo em três etapas: em primeiro lugar, descreve-se o conceito operacional de literatura adotado ao longo do trabalho. Em seguida, apresenta-se uma súmula do percurso da pesquisa, num esforço de mapear o desenvolvimento da reflexão aqui proposta, a partir da tentativa de identificar a origem da idéia de ficção entre os gregos antigos. Por fim, toma-se a obra de Luis Costa Lima para uma discussão sobre os conceitos de mímesis e de sua importância para o desenvolvimento de nossa hipótese inicial.
\end{abstract}

Palavras-chave: Conceito de Literatura; Ficção; Mímesis.

\section{Uma hipótese e um problema conceitual}

“A gênese da literatura está ligada ao surgimento da idéia de ficção”. O que poderia significar uma afirmação hipotética como esta?

A assertiva contém em si dois conceitos por si só problemáticos: “Literatura” e "Ficção". Especialmente no que se refere à conceituação da primeira, há, no universo dos estudos literários, uma “dissonância harmônica” entre os que garantem ser ilegítima qualquer definição - porque literatura significaria apenas e tão-somente qualquer coisa indicada como tal pelos falantes, não possuindo nenhum significado essencial para além do consenso de um grupo social, em determinado momento histórico - e aqueles que julgam impossível uma definição - devido ao caráter protéico da literatura, sempre insubmissa a categorizações. No uso cotidiano, porém, domínio da palavra, não do conceito, parece haver um inefável sentido implícito que nos permite um entendimento comum. Proponho então que, de modo provisório, deixemos em aberto tais definições e que procuremos elaborá-las ao longo deste ensaio.

Retorno então à nossa hipótese inicial, mas, atento ao problema dos conceitos, reapresento-a do seguinte modo: “Somente após os homens reconhecerem algo como sendo ficção - isto é, somente depois que o entendimento humano concebe a ocorrência de fenômenos cuja característica é situar-se entre os domínios do real e do falso - faz sentido pensar em Literatura”.

\footnotetext{
* Doutor em Literatura Comparada (UFF), Professor Adjunto de Teoria da Literatura (UERJ).
} 
Essa nova proposição implica uma primeira determinação de alguns aspectos conceituais. Por “Ficção”, proponho agora que se compreenda uma classe de objetos e eventos que se caracterizariam por exigir do sujeito uma transformação em seus processos cognitivos. Estou postulando que os objetos ou os eventos ficcionais não podem ser compreendidos através das mesmas categorias a que são submetidos os objetos, os seres, os eventos e os discursos tomados como descrições da realidade. Caso contrário, deixariam de ser “ficções” para se tornarem ilusões, enganos, simulacros, mentiras.

Em relação ao conceito de Literatura, submetido, neste primeiro momento, ao de Ficção, será necessário também um posicionamento: (I) entenderemos Literatura de tal modo que o atributo "literário” refira-se a algo presente no campo lingüístico? A marca que caracterizaria algum objeto como sendo "literatura" seria, portanto, efeito de um uso específico da linguagem verbal? (II) entenderemos a literatura como um comportamento social institucionalizado por alguns códigos de sentidos? Seria então "literatura” um conceito histórico que englobaria uma determinada prática cultural, circunscrita a limites espaciais e temporais?

Estaríamos assim diante de uma pergunta tradicional nos estudos literários: a literatura é um objeto ou uma relação? Ou melhor: a literatura é um objeto que determina uma relação ou viceversa? Num esforço de simplificação, podemos dizer que mesmo que admitíssemos a existência da "literariedade”, ou de um uso de linguagem que se poderia chamar de "poético", ainda teríamos de lidar com os modos de emprego e com os efeitos deste uso em determinados contextos sociais - o que nos leva a crer que os termos desta equação não se excluem mutuamente.

Não se quer dizer com isso que tal pergunta seja vã e que o engajamento a uma ou a outra concepção seja livre de conseqüências teóricas. No comentário preciso de Fortini:

Quando [...] se contesta a existência da literariedade [...] e se conclui que literário é apenas o que determinadas sociedades definem como tal, pretende-se [...] indicar, por ódio às investigações essencialistas, a relatividade histórica da noção de literatura. Mas [...] corre-se o risco de não avaliar o que nela há de comum entre a separação institucional dos textos literários, por exemplo, do século XIX francês ou inglês e a de épocas e sociedades remotas ou de culturas diversas. (FORTINI, 1989: 190-1)

Sendo nossa hipótese de trabalho a possível relação entre os "surgimentos” da ficção e da literatura na Grécia Antiga, parece que estamos alinhados a uma certa concepção essencialista dos fenômenos literários - fenômenos estes que existiriam independentemente desta ou daquela noção contida sob o vocábulo "literatura”. Afinal, estamos trabalhando com a idéia de que havia algo que pode ser chamado de "literatura grega antiga”, mesmo antes da existência do termo.

Posicionamentos como este são alvos de certo tipo de crítica, que julga serem tais formulações alheias aos papéis históricos desempenhados pelas experiências culturais relacionadas 
com as chamadas “artes verbais”. Por este prisma, postular a existência de literatura em tempos tão remotos ignoraria, especialmente, o processo de reconcepção do status dos discursos ocorrido nos séculos XVIII e XIX (Cf. SOUZA, 2006: 16-7). Há mesmo uma outra orientação para este problema, baseada numa hipótese de cunho nominalista: Michel Foucault, numa conferência em 1964, argumentava que a "literatura” não é assim tão antiga quanto tendemos a acreditar, mas “extremamente jovem em uma linguagem bastante velha” (FOUCAULT, 2000: 173). Se há milênios ocorrem fenômenos de linguagem que nos acostumamos a chamar de "literários", isso não evidenciaria a presença de nossa concepção de literatura em momentos históricos tão distantes quanto a Grécia ou a Roma Clássicas.

O ensaísta situará entre o final do século XVIII e o início do XIX, em torno de nomes como Chateaubriand e Mme. de Staël, o aparecimento desta forma especial de uso da linguagem. Antes disso, a acepção clássica de 'literatura' apenas designara, no século XVII “a familiaridade de alguém com a linguagem corrente, com as obras de linguagem” (FOUCAULT, 2000: 140). Em outras palavras, Foucault afirma que, sendo o termo 'literatura' recente, também o seriam os fatos literários, "razão por que expressões como 'literatura grega antiga', mais do que anacronismos, encerrariam verdadeiros nonsenses ontológicos” (SOUZA, 2006: 23).

Segundo Foucault, apenas quando o homem passa a desacreditar na capacidade de algum uso da linguagem humana traduzir o inefável, o incognoscível, o sagrado, dá-se a possibilidade do nascimento de uma consciência crítica a respeito do ser da literatura. A obra literária se esgotava, e "por razões puramente históricas, a literatura só foi capaz de se dar a si mesma como objeto" (FOUCAULT, 2000: 141). Teria sido o exato momento em que as normas da retórica e da poética clássicas caíram em desgraça, e a literatura passou, ela própria, a estar "encarregada de definir os signos e os jogos pelos quais ela vai ser, precisamente, literatura” (FOUCAULT, 2000: 147).

Percebe-se, na reflexão de cunho nominalista de Foucault, uma estranha visada ontológica pela qual a literatura só passa a existir quando se constitui um ser autônomo, auto-reflexivo e autotélico. Tal concepção de literatura é um produto de forças históricas que se fazem bastante visíveis a partir de meados do século XVIII. O que Foucault parece estar dizendo, de modo surpreendentemente tautológico, é que a literatura, como a entendemos hoje, existe apenas desde que a entendemos deste modo... Ou seja, sua convicção de que somente na modernidade a literatura pode existir justifica-se tão-somente porque seu conceito de literatura é estritamente moderno.

A inconsistência deste argumento revela-se já pela inexatidão de algumas de suas premissas. Entre elas, uma imprecisão filológica: o termo literatura não é tão recente quanto o filósofo nos faz supor. A etimologia da palavra leva-nos à língua latina, litteratura, um neologismo para litterae, coletivo de littera (letra do alfabeto). Litterae significa, a princípio, “carta” e depois, por extensão, 
“qualquer tipo de obra escrita”, além de “instrução, cultura”. Cícero (séculos II-I a.C.) já emprega tanto litterae quanto litteratura. Quintiliano (séculos I-II d.C.) emprega litteratura no sentido de conhecimento de ler e escrever. O percurso da palavra estende-se até o século XIV quando litterato indicava tanto o alfabeto quanto o homem de saber laico, como também qualquer coisa escrita com letras. O sentido de pessoa culta é conservado durante o Renascimento e será somente entre os séculos XVIII e XIX, com o advento da cultura romântico-burguesa, que os sentidos de escritos de imaginação, de invenção, artísticos e de função estética se tornam as principais acepções da palavra (FORTINI, 1989. passim).

Há ainda outra fragilidade na argumentação de Foucault. Não parece ser correto afirmar que a desconfiança sobre o caráter "sagrado" da escrita seja um fenômeno exclusivo do século XIX. A distinção entre litteratura (um conjunto de textos cujo conteúdo refere-se a humanidades em geral) e scriptura (textos que abrangem tanto a Sagrada Escritura quanto tratados de teor religioso) remonta a escritores como Tertuliano e Cassiano, do século II d.C.. No Renascimento, a existência da expressão litterae humanae confirma a permanência de uma separação entre letras seculares e sagradas (Cf. SOUZA, 2006: 1-3).

Uma terceira inconsistência da hipótese nominalista de Foucault é apontada por Roberto Acízelo de Souza: tanto a identificação de uma certa modalidade discursiva específica (que hoje chamamos de "literatura”) quanto as tentativas de se reconhecê-la em termos teóricos e analíticos, ao contrário do que Foucault postula, são antigas. Tomado o vasto âmbito da linguagem verbal, a circunscrição “literatura” ou suas, digamos sem muito rigor, equivalências históricas não são, exatamente, uma invenção de nossos dias. Como exemplo, cita um trecho da Poética, de Aristóteles, que transcrevo abaixo:

se alguém compuser em verso um tratado de medicina ou de física, esse será vulgarmente chamado de "poeta"; na verdade, porém, nada há de comum entre Homero e Empédocles, a não ser a metrificação: aquele merece o nome de "poeta", e este, o de fisiólogo, mais que o de poeta. Pelo mesmo motivo, se alguém fizer obra de imitação, ainda que misture versos de todas as espécies [...] nem por isso se lhe deve recusar o nome de “poeta” (ARISTÓTELES: 1991: 202).

Observa-se já em Aristóteles o esforço de se distinguir especificidades discursivas. No caso em questão, o filósofo encontra na mímesis, mais do que na métrica, o aspecto mais significativo do tipo de discurso que ele identifica como poiésis. Acízelo nota ainda que a existência de características específicas a certos modos discursivos “independe da disponibilidade de uma palavra genérica que os nomeie, contrariando-se assim o pressuposto nominalista de que o designans é no caso em apreço coextensivo ao designatum" (SOUZA, 2006: 33). Como exemplo, novamente Aristóteles: 
Mas [...] a arte que apenas recorre ao simples verbo, quer metrificado quer não, e, quando metrificado, misturando metros entre si diversos ou servindo-se de uma só espécie métrica eis uma arte que, até hoje, permaneceu inominada. Efetivamente, não temos denominador comum que designe os mimos de Sófron e de Xenarco, os diálogos socráticos e quaisquer outras composições imitativas, executadas mediante trímetros jâmbicos ou versos elegíacos ou outros versos que tais (ARISTÓTELES: 1991: 201)

Dessa crítica a Foucault, podemos tirar alguns balizamentos importantes para o desenvolvimento de nosso trabalho. Refiro-me, sobretudo, a como tanto o termo "literatura” quanto a modalidade discursiva que se destaca dos textos sagrados e religiosos, dos discursos da Verdade (científicos, filosóficos) e dos discursos pragmáticos gerais têm um longo percurso na cultura ocidental. Se é correto se duvidar de abordagens que procurem entender, a partir de parâmetros analíticos e valorativos contemporâneos, produtos discursivos de outros momentos históricos, não é exato refutar a possibilidade de falarmos em “obras literárias” de períodos como a Grécia Clássica simplesmente porque seriam concepções anacrônicas à palavra ou ao nosso entendimento contemporâneo do termo. A conceituação de uma atividade cultural humana não pode ser elaborada tomando-se exclusivamente a forma atual do objeto, como se esta fosse definitiva, mais aperfeiçoada ou exata. Entre o conceito teórico e o objeto concreto há de haver uma instância intermediária de enunciados que postulem, com algum grau de idealização, algum elemento transhistórico, não como algo fixo, imutável e fora da ação do tempo, mas como algo que, de algum modo, permanece, ainda que com diferenças, ao longo do tempo. Apenas neste sentido julgo possível uma atividade reflexiva que mantenha uma resistência e uma distância do objeto cultural concreto. Do contrário, qualquer teoria literária corre o risco de se converter num contínuo referendar a criação artística de seu tempo, sem condições de criticar o valor de tais práticas.

O entendimento contemporâneo hegemônico de literatura não pode ser privilegiado como sendo o produto mais bem acabado de uma linha evolutiva conceitual. Ainda que se recuse a chamar de literários textos produzidos antes da existência da palavra "literatura”, não se pode negar a existência de uma certa produção discursiva que ocupava, no nosso caso específico, a cultura grega antiga, um espaço próprio. É este tipo de produção textual, que não se alinha nem com os discursos religiosos ou sagrados, nem com os discursos da verdade (científica ou filosófica), que surgirá, assim estamos propondo, a partir do surgimento da idéia de ficção.

Penso ter estabelecido um campo mínimo de trabalho, a partir do qual posso falar agora em literatura sem tantas ambigüidades conceituais. Reformulo, então, novamente a hipótese inicial: "Somente após os homens reconhecerem algo como sendo da ordem do ficcional - isto é, somente depois que o entendimento humano concebe a ocorrência de fenômenos cuja característica essencial é a de situarem-se entre o domínio do real e do falso - faz sentido pensar numa circunscrição específica dos discursos que chamaremos, modernamente, de Literatura. Passo então a lidar 
diretamente com a idéia do surgimento da ficção, tentando compreender como ocorreu, entre os gregos antigos, a transformação no entendimento humano que faz com que determinados discursos ou objetos sejam apreendidos não mais como elementos da realidade imediata, mas como construções técnicas que produzem um certo efeito de realidade.

\section{Notas de percurso: no rastro da origem da ficção}

No livro II da República, na passagem em que se discute o tipo de educação a ser dada aos guardiães (ginástica, para o corpo, e musiké $e^{1}$, para a alma), Sócrates pergunta a Adimanto se ele considera que se deve incluir o lógos entre os ensinamentos da musiké. Diante do assentimento de seu interlocutor, Sócrates pondera:

- São duas as espécies de discursos [lógos], a dos verdadeiros e a dos falsos?

- Sim.

- Devemos educá-los [os jovens] com ambos, mas primeiro com os falsos [pseudós]?

- Não estou entendendo o que dizes, disse.

- Não entendes, disse eu, que primeiro contamos mitos às crianças? No seu todo, eles são mentirosos, mas neles há verdades também. (PLATÃO, 2006: 74)

Sócrates refere-se a uma espécie de lógos que denomina de pseudós. A serena anuência de Adimanto indica que a idéia de uma região intermediária entre a verdade e a mentira e a aceitação de um tipo de lógos que não comunica o real já não eram novidades a esta altura do século IV a.C. Não se tratava, porém, de um tema consolidado e livre de contradições, mas de um elemento central em uma querela que se arrasta até nossos dias: a diaphorá entre Filosofia e Literatura, o embate, no campo do lógos, pelo direito e pelo poder de revelar a verdade.

Por tradição, a poesia era uma das detentoras da alétheia ${ }^{2}$. Os filósofos passaram a contestar essa supremacia, alegando que a verdade revelada pela poesia, por não apresentar a forma de um discurso argumentativo, estaria num plano além (ou aquém?) dos limites do conhecimento humano. A “revelação” da poesia não seria um saber efetivo, pois não poderia ser subsumida ao rigor de uma techné. Para comentadores como Havelock (1996), A República, encenaria justamente o conflito entre a tradição oral representada pela poesia e a emergência de novos saberes, representados pela Filosofia. A proposição de Platão é a de que se chamasse de lógos ao discurso filosófico e de mýthos ao tipo de narrativa presente na poesia (literatura).

Em sua etimologia, a raiz da palavra lógos, [lég-], remete a dois sentidos do verbo “contar” em português: I) o de “computar, verificar o número, a quantidade de algo"; II) o de "narrar, relatar”. Platão propõe um melhor ajuste do significado com a expressão dídonai lógon, algo como

\footnotetext{
1 “Artes das musas” e não simplesmente “música” como aparece na tradução citada. Musiké tem um sentido próximo de cultura geral.

2 O radical leth significa esquecimento, ocultação. A-leth, portanto, é “aquilo que se desoculta”, “que sai do esquecimento”, “que se revela”, "revelação”. Geralmente, traduz-se por “verdade”.
} 
“dar conta de”, “oferecer um discurso justificativo, explicativo e esclarecedor sobre um objeto”, algo próximo do que hoje entenderíamos por “conceituar”. Já mýthos se manteria como um discurso predominantemente narrativo. O filósofo reclama assim, para o domínio do lógos, o privilégio de alcançar a Verdade, enquanto que caberá ao mýthos um estatuto secundário na hierarquia dos discursos.

Quando Platão, no trecho da República que transcrevemos acima, refere-se aos mitos, tem em mente obras como a épica homérica. Sabemos, contudo, que nessas epopéias não se distingue entre mýthos e lógos quando a referência é a idéia de narração. Ora, estamos obrigados então a atentar para uma desigualdade basilar: a relação que o homem grego do século IV a.C. mantinha com a Ilíada e a Odisséia era absolutamente distinta do modo como o homem grego do século VIII a.C. compreendia essas mesmas epopéias. Embora pareça um tanto óbvia, tal diferenciação nem sempre é suficientemente salientada. Tome-se, como exemplo, Mímesis, a obra clássica de Erich Auerbach.

No primeiro ensaio, “A cicatriz de Ulisses”, Auerbach (1994) argumenta que a realidade é percebida nos poemas homéricos através do compartilhamento da excelência da vida heróica, sendo indiferente, para o leitor, "saber que tudo não passa de lenda, que é tudo mentira” (AUERBACH, 1994: 10). A epopéia homérica, em sua manifestação de alegria pela existência sensível da vida, substituiria, momentaneamente, a realidade imediata. Seu estatuto é o da verossimilhança e seu objetivo é encantar através de um apelo estético.

Para o ensaísta, o mundo criado por Homero em suas epopéias é existente por si só. O estilo homérico caracterizar-se-ia ainda por não deixar nada do que é mencionado na penumbra ou inacabado, representando sempre "os fenômenos acabadamente, palpáveis e visíveis em todas as suas partes, claramente definidos em suas relações espaciais e temporais” (AUERBACH, 1994: 4). Comparando a épica homérica ao Velho Testamento, Auerbach chama a atenção para a falta de descrição e de localização espacial do deus no texto bíblico, que “aparece” sempre carente de forma, apenas como uma voz vinda de algum lugar não explicitado. Isso não seria apenas indicativo das diferentes noções de divindade na cultura grega antiga e na judaica, mas um sintoma do “particular modo de ver e de representar” (AUERBACH, 1994: 4) em cada uma dessas sociedades.

Ao contrário do que ocorreria em Homero, haveria, na épica bíblica, uma exigência de verdade histórica. O texto bíblico pretenderia suplantar a realidade imediata do leitor. Seu estatuto seria o da verdade única e seu objetivo o de dominar o leitor através de um apelo racional. Em outras palavras, enquanto a narrativa homérica posicionar-se-ia na fronteira do lendário, o Velho Testamento mover-se-ia em direção ao relato histórico. 
Auerbach faz notar que, para o leitor as diferenças entre lenda e história são de mais fácil identificação do que aquelas entre verdade e mentira. Uma lenda se distingue não apenas por seu conteúdo de caráter fantástico, mas também formalmente, por elementos como a estrutura linear, a ausência de elementos transversos e de contradições, a ordem simplista etc.

As distinções conteudísticas e formais entre verdade e não-verdade, real e irreal, lenda e história seriam tão assentes para um grego do século VIII a.C.? A reflexão de Auerbach só faz sentido se admitirmos que os gregos já haviam passado por marcantes transformações culturais em especial, uma reformulação no plano da apreensão da realidade, que lhes teria permitido aceitar o que chamaremos provisoriamente de pacto ficcional, isto é, a possibilidade de se perceber a “existência irreal” de algo.

Um dos caminhos investigativos adotados ao longo da pesquisa que originou este ensaio foi o rastreamento, com Jean Pierre Vernant, da origem da representação figurada entre os gregos. A capacidade de figuração, lembra-nos o helenista, não seria uma constante universal do homem, mas uma categoria histórica, que implicaria o desenvolvimento prévio de algumas habilidades e noções:

Trata-se de um quadro mental que, em sua construção, supõe que já se tenham singularizado e delineado nitidamente, em suas relações mútuas e em sua oposição comum ao real, ao ser, as noções de aparência, de imitação, de semelhança, de imagem, de simulacro. O advento de uma plena consciência figurativa opera-se em particular no esforço feito pelos antigos gregos para reproduzir em uma matéria inerte, graças a artifícios técnicos, o aspecto visível daquilo que, vivo, manifesta-se imediatamente ao olhar seu valor de beleza - de divina beleza - como thaûma idésthai, maravilha de se ver. (VERNANT, 1973: 310)

Se tomarmos uma linha cronológica da estatuária grega, observaremos um processo de transformação que, partindo das simples atualizações simbólicas da divindade, chega à elaboração da imagem propriamente dita, isto é, da "imagem concebida como um artifício imitativo que reproduz, na forma de um simulacro, a aparência externa das coisas reais” (VERNANT, 1973: 296). Vernant identificará o momento em que o símbolo de uma potência do além se transforma em uma imagem - isto é, numa produção técnica, feita por um especialista que emprega procedimentos ilusionistas - como a inauguração da categoria do fictício, ou, em outras palavras, da categoria daquilo que chamamos hoje de arte.

Sob o ponto de vista moderno, o ídolo arcaico, o xóanon, não é uma imagem. Sua forma não importa tanto quanto sua investidura simbólica. Sua origem mítica é descrita como não tendo sido fabricado por mãos mortais. Trata-se, sobretudo, de um elemento ritual:

O símbolo não representa o deus, abstratamente concebido em si e para si; não procura instruir-nos sobre sua natureza. Expressa a potência divina, enquanto manejada e utilizada por determinados indivíduos, como instrumento de prestígio, meio de domínio e de ação sobre os outros. (VERNANT, 1973: 301) 
A estátua, entretanto, constitui um modo de representação completamente novo. O símbolo divino aparece agora parcialmente liberto do ambiente restrito do ritual e se relaciona com a “descoberta do corpo humano e de uma conquista progressiva de sua forma” (Ibid., p. 303). Ao contrário do que ocorria com o xóanon, a reprodução do aspecto humano agora é essencial. Mas como, quando e por que razão se teria dado tal transformação radical?

Vernant indica duas palavras centrais para se fazer uma reflexão sobre a imagem entre os gregos, ambas etimologicamente relacionadas ao campo semântico da visão e do semblante: Eídôlon e Eikôn. Os dois termos são empregados desde a idade clássica até a época bizantina para designar todas as formas de imagens artificialmente fabricadas, bem como as imagens de origem natural, como os reflexos, as sombras etc.

Alguns especialistas identificam que há uma profunda diferença entre Eídôlon e Eikôn no que tange a relação da imagem com o seu referencial. Eídôlon seria uma espécie de cópia da aparência sensível do que é representado, um simulacro voltado exclusivamente ao olhar do observador, enquanto que Eikôn, uma espécie de transposição da essência voltada para a inteligência do observador, isto é, uma representação que evocaria uma comparação entre as qualidades e os valores da representação e do que é representado. Esta distinção seria claramente intensificada e consagrada no Império Bizantino, quando Eídôlon assume definitivamente seu caráter negativo em oposição a Eikôn. O Cristianismo medieval confirmará a oposição entre ídolo e ícone, como forma de demarcar a distinção que lhe interessava entre as estátuas de falsas divindades e a figura do verdadeiro deus. Esta classificação, contudo, não ocorria entre os gregos.

Na Grécia antiga, três eram os empregos do termo Eídôlon: I) nos aparecimento de caráter sobrenatural (phásma); II) nas imagens dos sonhos (óneiros); III) na referência às almas dos mortos (psykhé). Nos três casos, Eídôlon consiste num modo de aparecimento "estranho”, como anota Vernant: "Ele [o eídôlon] é de fato o aparecer, mas de quem não está presente; sua presença é a de um ausente. Mas a ausência que o Eídôlon carrega não é totalmente negativa; não é a ausência do que não existe, de um nada, mas de um ser que não pertence ao nosso mundo” (VERNANT, 1973: 317).

Se o estatuto de Eídôlon em Homero é o da perfeita aparência que conduz ao engano, devese lembrar também que não há, nos tempos homéricos, uma polarização entre Eídôlon e Eikôn. O surgimento dos dois termos não é contemporâneo. Eikôn apenas aparece no século V a.C., simultaneamente com o grupo de palavras usadas para expressar imitação e simulação: mímos, mimêma, mimeîsthai, mímesis. Vernant observa que estes termos são empregados em relação às artes em geral, mas estão particularmente ligados à instauração de um novo tipo de obra, o espetáculo dramático, cuja originalidade “consiste em presentificar aos olhos do público, para que 
este os veja diretamente em cena, personagens e acontecimentos 'fictícios’ que a epopéia contava em forma de relato, em estilo indireto” (VERNANT, 1973: 315). Mímesis passará então a ocupar o lugar de Eídôlon no sentido de imagem voltada para a aparência visual.

Nossa hipótese de trabalho agora se confunde com a questão formulada por Vernant:

Em que momento ela [a imagem] adquiriu as características que farão com que Platão a defina como uma ficção, um não-ser, que não possui outra realidade senão a 'similitude' com o que não existe: em suma, quando a imagem passou a ser apreendida como um simulacro, produto ilusório de um artifício imitativo (VERNANT, 1973: 315)

No plano do lógos, a ascensão da sofística e a preocupação manifestada por Platão com a veracidade e a falsidade discursivas revelam-nos um processo de reestruturação que reavaliou a potência e a função dos discursos na sociedade grega clássica. Duas obras, com perspectivas bastante antagônicas, parecem-me emblemáticas desta nova realidade: de um lado, o famoso Elogio a Helena, em que Górgias (1993), empreendendo algo próximo a uma teoria do discurso, identifica no lógos a potência divina (dynástes mégas, capaz de realizar theióstata érga). Do outro, a teoria platônica da imagem sistematizada no Sofista. Nesse diálogo, Platão identifica que a razão do prestígio granjeado pela sofística encontra-se exatamente no poder de criar ilusões. Os sofistas, através de uma técnica discursiva, seriam capazes de apresentar, a propósito de tudo, ficções verbais que dariam a ilusão de se tratarem de verdades sobre todas as coisas. Porém, para demonstrar que qualquer homem que se julgasse capaz de, através de uma única arte, tudo produzir não fabricaria senão imitações e homônimos da realidade (Cf. PLATÃO, 1991: 151), o Estrangeiro de Eléia precisa admitir que uma imagem não pode ter um status pleno de não-ser, isto é, a imagem não é absolutamente irreal e não-verdadeira - do contrário, como seria possível a enunciação de algo que simplesmente não é? Platão comete assim o que ele mesmo chama de "parricídio intelectual”, vendo-se obrigado a discordar da tese da unicidade do ser de seu mestre Parmênides e de reconhecer a paradoxal possibilidade de existência de um não-ser: o falso lógos.

O modo como Platão ataca o falso lógos e a produção de falsas imagens não atinge apenas os sofistas, mas também um procedimento fundamental das artes: a mímesis. Não cabe nos limites deste ensaio uma discussão do conceito de mímesis em Platão, em virtude do caráter contraditório do tratamento dado pelo filósofo ao tema. Contudo, não é satisfatório lidar com o entendimento de mímesis como uma mera técnica de imitação - uma suposta herança platônica. Foi nesse ponto que avaliamos ser produtivo introduzir em nossa investigação os trabalhos de Luís Costa Lima.

\section{O problema da mímesis: a revisão de Costa Lima}

O trabalho de Luís Costa Lima aqui abordado estrutura-se inicialmente como um projeto de revisão do conceito renascentista de fenômeno mimético, a fim de combater um conseqüente 
preconceito moderno em relação ao alcance e à funcionalidade da categoria da mímesis para o pensamento contemporâneo sobre a arte. Sua proposição central é a de que não se deve compreender a mímesis estritamente como um processo produtor de semelhanças, mas, também e sobretudo, de diferenças. Ao traduzir mímesis por imitatio, o Renascimento reduziu-a a um processo de multiplicação de semelhanças - não por acaso, as normas poéticas classicistas submeteram a produção artística à obediência rígida de modelos. Herdando a tradição deste entendimento redutor do fenômeno, a era moderna impôs a mímesis a condição de uma antiqualha do pensamento teórico ocidental. O desdém analítico votado ao tema fez com que fossem obscurecidas marcantes diferenças epistemológicas entre, por exemplo, as concepções platônica e aristotélica. Para demonstrar as tensões presentes já na origem do reconhecimento do processo mimético e indicar assim que, menos que um ato orientado por um desejo de cópia, a mímesis compreende uma fusão de um modelo com a potencialidade própria do agente mimético, Costa Lima empreenderá um breve excurso histórico, em busca das primeiras reflexões sobre o tema. Nosso intuito em acompanhar sua reflexão é o de nos munir com subsídios teóricos que nos permitam avançar em nossa investigação, tendo sempre em mente que, para o autor, a ficção é o produto direto da mímesis.

Tomando o trabalho do filólogo Göran Sörbom, o ensaísta experimenta uma pequena análise da ocorrência do termo mimeisthai e de seus correlatos em autores anteriores a Platão. Sua conclusão é a de que, em linhas gerais, o tratamento dado ao mímema ressaltava seus traços de semelhança com o real. Contudo, já neste período, por ele denominado de pré-conceitual, a mímesis implicava tanto a equivalência quanto a diferença (LIMA, 2000: 297). Isso porque não se deve entender por "semelhante” apenas uma "réplica” ou uma “cópia”, mas algo que possibilite o estabelecimento de uma relação de “correspondência”. A título de exemplificação, o ensaísta comenta os vestígios de supostos procedimentos miméticos que haveria no pitagorismo. Tais métodos possuiriam uma função terapêutica, isto é, a reprodução de estados e processos anímicos através da música e da dança produziria uma espécie de medicina da alma. O ato mimético obedeceria assim a um modelo orgânico e convergiria com os desígnios da Natureza, atuando não como mera duplicação, mas como um processo que, de algum modo, complementa a realidade, ainda que sujeita ao jugo estrito das leis naturais. Todavia, neste tipo de mímesis - que ele denomina “clássica” - mesmo quando o vetor diferença é considerado, ele está subordinado à semelhança, “embora, em termos aristotélicos, antes homóloga à natura naturans, i. e., produtora de formas, que à natura naturata, i. e., considerada quanto às formas já produzidas” (LIMA, 2000: 24).

Entre as formas passíveis de serem produzidas pela mímesis, Costa Lima identifica uma que nos interessa sobremaneira: a imagem ilusória. Referindo-se à célebre anedota acerca da “vitória” 
do pintor Parrhasius sobre Zêuxis, o ensaísta acena para como já se percebera a potência ilusionista da mímesis, o que seria uma indicação de que “a convergência dos interesses humanos com as propriedades da natureza” (LIMA, 2000: 300) não seria mais tão plena.

A tensão existente no período pré-conceitual entre a semelhança (o domínio da ilusão) e a diferença (o domínio da criação) fundaria as duas grandes vertentes gregas de compreensão da mímesis: a platônica e a aristotélica. Tradicionalmente, Platão encabeçaria uma longa linhagem de pensadores que desprezariam o fenômeno mimético por julgá-lo apenas reprodutor de aparências ilusórias, enquanto que Aristóteles corresponderia ao marco zero daqueles que privilegiam o potencial criativo da mímesis.

Para falar de Platão, Luís Costa Lima remete a um ensaio de Paul Woodruff, em que a recusa platônica da mímesis é situada em dois planos, um pedagógico e outro ético-epistemológico. Grande parte da rejeição platônica é motivada por sua desconfiança sobre a pretensa capacidade cognitiva da mímesis. Sendo uma prática que não conduzia a nenhum conhecimento efetivo, mas possuidora de uma potência capaz de produzir efeitos pathétikos quase incontroláveis e, sobretudo, sem nenhum télos que a justificasse, a mímesis não deveria poder ocupar um espaço de destaque no pensamento platônico.

Já para Aristóteles, importaria menos que a mímesis não fosse uma forma de epistéme - ou seja, no sentido forte de téchne, uma fonte de conhecimento organizado. O filósofo reconhecia nela um outro modode potência cognitiva, capaz de abrir uma “segunda porta” de acesso à verdade: concomitante à filosofia como via de apreensão ao real haveria o que Costa Lima chama de "engano poético” (LIMA, 2000: 32). Em outras palavras, citando James M. Redfield, diz o ensaísta que o objeto mimético é um produto de “alguma intuição abrangente, ainda que esquemática, dos padrões encontrados na experiência” (LIMA, 2000: 32). E complementa mais adiante: "Sem ser didática, abominando mesmo qualquer didatismo, a obra de arte entretanto ensina. A questão consiste em saber o que a coletividade em causa se dispõe a aprender com ela.” (LIMA, 2000: 69).

Em Aristóteles, o mímema não está, como em Platão, subordinado ao eidos, mas em ambos “a mímesis supõe um ato de adequação ou correspondência entre a imagem produzida e algo anterior - em Platão, anterior e superior - que a guia” (LIMA, 2000: 34). A diferença é que, para o filósofo de Estagira, entre o objeto mimético e seu correspondente anterior haveria a consideração a uma dimensão intermediária, a da linguagem, onde atuaria a metáfora. E será justamente a transformação de sentido operada pelo discurso metafórico que abriria a outra porta para a verdade.

A inserção da metáfora para a compreensão da mímesis torna ainda mais diversos entre si os enfoques platônico e aristotélico. A produção de sentidos metafóricos depende do estabelecimento de relações analógicas. E a analogia, por propor um vínculo de semelhança entre duas coisas 
distintas, não é o método mais adequado para se atingir a ousía dos seres ou das coisas. Tal problema, como vimos anteriormente, já havia sido experimentado por Platão no Sofista, quando o Estrangeiro de Eléia precisa cometer o “parricídio intelectual” contra Parmênides e abandonar a tese da unidade do ser para garantir a possibilidade de existência de falsas imagens. A presença da metáfora no pensamento de Aristóteles inviabiliza assim o potencial cognitivo epistêmico da mímesis e reforça a necessidade de se admitir a validade de pensar a "dupla entrada que o intrincado da vida exige” (LIMA, 2000: 36) como forma de garantir a legitimidade criativa do fenômeno mimético. Costa Lima observa que o modo como os pensadores da Idade Média incorporaram o pensamento de Aristóteles às doutrinas do Cristianismo é o responsável pela obnubilação, na história da reflexão sobre a mímesis, da possibilidade da dupla entrada para a verdade, em favor da unificação de Deus. Afinal: “Como a concepção de um Deus único, onipotente e magnânimo seria conciliável com a legitimação de um sistema filosófico que acatava a validade do engano, a suspensão provisória da verdade como maneira de emocionalmente experimentá-la?” (LIMA, 1993: 40).

Completado o percurso do conceito de mímesis na Antigüidade, a que concepção funcional do fenômeno postula Luís Costa Lima? Mesmo sem se propor defini-la de modo categórico, o ensaísta arrola algumas características significativas: (I) A mímesis é um fenômeno da existência, não apenas um conceito operacional; (II) Quando, por razões teóricas, transformamos a mímesis em conceito, devemos entendê-la como uma noção transversal e transtemporal, válida, por exemplo, para os dois grandes momentos históricos da literatura e da arte em geral: o período autônomo, característico da modernidade, e o pré-autônomo; (III) Ainda que o campo da Estética tenha criado quase um monopólio do debate sobre o tema, a mímesis não é uma especificidade de linguagem limitada às artes. Não há um discurso específico onde ele opere. Há objetos miméticos artísticos assim como objetos miméticos cotidianos e tal atributo é definido não pelo tipo de mímesis em si, mas pelas molduras historicamente configuradas que reconhecem como tais umas e outras; (IV) Ensaiando uma definição em termos formais e de modo geral, Costa Lima dirá que “a mímesis supõe a correspondência entre uma cena primeira, orientadora e geral, e uma cena segunda, particularizada numa obra. Esta encontra naquela os parâmetros que possibilitam seu reconhecimento e aceitação” (LIMA, 2000: 22). Ele atenta, porém, para que não se confunda “cena orientadora” com “cena modelar”, pois esta, ao contrário daquela, implicaria um caráter normativo, inadequado à sua concepção de mímesis. O que o ensaísta entende por “cena primeira” não é uma cena material, mas um conjunto de parâmetros culturais que guiam o receptor.

A noção de parâmetros culturais remete ao conceito gadameriano de "horizonte”. O horizonte da experiência é uma limitação histórica, temporal e espacial, das possibilidades de 
entendimento. O horizonte estabeleceria uma certa indução que pertence a toda produção de enunciados e é inseparável dela, constituindo - como uma modalidade de inteligibilidade já elucidada - uma espécie de estrutura de antecipação de julgamentos. Os parâmetros culturais são, para Costa Lima, os responsáveis pelo aparecimento da Verossimilhança. Porém, num modelo de mímesis em que se destacam os aspectos geradores de semelhança, privilegia-se tão-somente o aspecto negativo do verossímil, isto é, sua força cristalizadora e resistente a produções que não o obedeçam. Com isso, o ensaísta pretende que a criação da verossimilhança seja entendida como uma potência da obra mimética, ressalvando, entretanto, que o mímema não apenas se alimenta da realidade, mas é também capaz de modificar a própria visão da realidade do espectador.

A verossimilhança incorpora o receptor como elemento ativo do processo mimético. Em conseqüência, Costa Lima pondera que a mímesis não pode ser pensada exclusivamente no plano do indivíduo, seja ele o produtor ou o receptor das imagens. O efeito mimético ressoa, necessariamente, numa coletividade: “Sem visar imediatamente à comunicação, a obra de arte traz em si aquilo de que a comunicação depende: a comunidade de um código, mesmo que, na obra, haja do código apenas restos” (LIMA, 2000: 57).

A verossimilhança é, portanto, a manifestação da correspondência entre o mímema e a classificação social que impulsiona a produção de sentidos. E, como tal, deve manter algum tipo de relação com aquilo que se convenciona entender por verdade num determinado contexto. Afinal:

se a obra cortar todas as amarras com a verdade - i. e., com o que a sociedade em causa, de acordo com a "classificação" que a atravessa, toma por verdade -, constituirá, no melhor dos casos, um mundo paralelo que, não identificável com qualquer aspecto do 'real', em princípio, não permitiria ao leitor nenhuma entrada (LIMA, 2000: 61).

O verossímil possibilita ao mímema, através do aconceitualismo das imagens, uma perspectivação da verdade, o que faz da obra de arte um produto crítico sem ser didático. Em outras palavras “a ficção não representa a verdade, mas tem por ponto de partida o que os produtores e receptores têm por verdade” (LIMA, 2000: 64). Como efeito primário da mímesis, o verossímil organiza o quadro de expectativas para que da semelhança possa emergir a diferença. E, finalizando: “a retomada da questão da mímesis supõe, de início, menos um corte com sua concepção antiga do que o realce do que, nela existente, permanecia recalcado” (LIMA, 2000: 304).

Assimilando a noção de mímesis desenvolvida por Costa Lima, procuraremos, num esforço de conclusão, relacioná-la com nossa hipótese inicial, devidamente alterada: "Somente após os homens reconhecerem o objeto mimético como sendo da ordem do ficcional - isto é, somente depois que o entendimento humano concebe a ocorrência de fenômenos cuja característica essencial é a de situarem-se entre o domínio do real e do falso - faz sentido se pensar numa circunscrição específica dos discursos que chamaremos, modernamente, de Literatura”. 


\section{Considerações finais}

O objetivo deste ensaio foi o de pensar como uma transformação da mentalidade do homem antigo fez com que a ficção assumisse um papel de destaque na cultura ocidental. Não parecendo ser a ficção um universal do homem, podemos supor que, na contemporaneidade, estamos presenciando um esgotamento das fórmulas ficcionais, ou uma mudança radical dos paradigmas de verossimilhança, talvez pelo enfraquecimento ou mesmo desaparecimento daquelas condições que foram determinantes para o surgimento da ficção entre os gregos. Abriríamos, deste modo, uma via de pesquisa que nos possibilitaria refletir sobre as relações existentes, na modernidade, entre a crise da arte e a crise da ficção.

Para tanto, entender o estatuto do objeto ficcional é uma tarefa premente e incontornável. E um dos pré-requisitos fundamentais seria conseguir situar, satisfatoriamente, o momento do aparecimento da ficção entre os gregos. Teria sido, como sugere Vernant, no momento em que a figura humana deixou de encarnar valores religiosos e passou a "existir em si e por si, em sua aparência, como um modelo a ser reproduzido” (VERNANT, 1973: 307)? Ou, como também aponta o helenista, a tragédia foi realmente o marco desta mudança cognitiva e, por conseguinte, o espectador trágico foi o receptor característico das técnicas ilusionistas miméticas? Afinal, mal comparando a tragédia ao impacto causado pelo surgimento do cinema no século $\mathrm{XX}$, podemos dizer que as novidades tecnológicas do espetáculo trágico obrigaram a uma mudança de percepção para suportar a incrível aparência de realidade das cenas apresentadas e então entendê-las como fictícias.

Estaríamos dizendo com isso que a Grécia pré-trágica era um mundo sem imagens, em que os sentidos humanos eram a fonte segura de toda a veracidade? E, por outro lado, o nosso mundo contemporâneo, saturado de ficções, estaria vivendo uma "sede de real”, por estar incapaz de compreender o grau de realidade que as imagens carregam? Ou ainda: se não existe, na Grécia Clássica, objetos com uma teleologia do belo, isto é, objetos com “fins estéticos”, qual seria pois o télos e a utilidade da obra de ficção? Tais perguntas se multiplicarão em cascata sem que possamos respondê-las se não enfrentarmos o problema central da natureza das “imagens” ficcionais.

Wolfgang Iser (1996) sugere que a ficção não pode ser compreendida apenas por uma oposição direta à realidade. O texto ficcional contém elementos da realidade sem que se esgote nele a descrição deste real. Logo, o componente fictício do texto ficcional não é um fim em si mesmo, mas é a preparação de uma terceira coisa que mantém com o real e o falso uma relação assombrada pelo mistério da mímesis, há séculos mal compreendida. Por meio do projeto de revisão de Costa Lima, observamos como não apenas ele, mas toda uma longa estirpe de filósofos e teóricos da arte lidam com pretensas teorias da mímesis platônica e aristotélica, sem ter como explicar as 
contradições, na obra de Platão, entre a crítica à aparência e o modelo mimético na teoria das formas, ou, num filósofo tão atento para a necessidade de se estabelecer definições formais como Aristóteles, a ausência de um conceito explícito de mímesis.

Uma potência da mímesis, certamente, seria a de causar ilusão, ou seja, um erro de percepção, fenômeno através do qual uma coisa se faz passar por outra. Note-se, porém, que tal funcionamento é idêntico ao que geralmente se entende por “representação”, isto é, a instituição de um representante, de algo que, em determinado contexto, toma o lugar daquilo que representa.

Se, em nossa cultura, a idéia de representação é, se não apreciada, ao menos tolerada ou tida como estrategicamente útil, poderíamos talvez dizer que a ilusão é a versão historicamente desvalorizada da representação. O ilusionista possuiria uma intenção dolosa, pois proporia uma representação sem que o receptor a percebesse como tal. Ocorre, porém, que ambas, ilusão e representação, são dependentes de uma codificação social. Num exemplo elucidativo:

Para um apreciador europeu do século XIX, a pintura de uma cabana polinésia mais parecia um borrão sem valor artístico; ao contrário, os primeiros papuas da Nova Guiné a quem se mostraram fotografias acharam estas imagens estranhas, difíceis de compreender e esteticamente sem graça - porque muito pouco esquematizadas. (AUMONT, 1995: 105)

As técnicas de produção de imagens não são capazes de substituir por completo aquilo que é representado e reproduzem apenas parcialmente a realidade. Mesmo porque, como nos lembra Nelson Goodman, em Languages of art, a noção de imitação simples e pura não faz sentido, pois não se pode copiar o mundo tal como ele é, simplesmente porque não se sabe como ele é. A imagem não é, pois, um duplo perfeito do objeto representado, o que significa dizer que a ilusão não é uma réplica, mas uma duplicação de alguns aspectos da aparência.

Se a criação da ilusão, isto é, de uma representação não percebida como tal pelo receptor, respeita também a uma convenção, "Realismo ilusório” e "Verossimilhança crítica” seriam pontos extremos da percepção de imagens ficcionais. Uma imagem dita realista respeitaria ao máximo as convenções sociais da representação ou retiraria da própria técnica que a produziu sua legitimidade como expressão do real. O melhor exemplo é a fotografia:

o poder de convicção da fotografia [...] provém do saber implícito ou não que o espectador tem sobre a gênese dessa imagem [...] Porque sabemos que a imagem fotográfica é uma marca, um traço automaticamente produzido por procedimentos físico-químicos [...], acreditamos que ela representa de forma adequada essa realidade e estamos prontos para crer eventualmente que diz a verdade a seu respeito (AUMONT, 1995: 113).

Por outro lado, uma imagem verossímil seria a de fraco realismo, mantendo com a compreensão do real apenas algum tipo de relação analógica potencialmente criadora de sentidos não presentes na cena orientadora do processo mimético. Como propõe Costa Lima: “A experiência 
do ficcional supõe a experimentação do que não se conhece, empreendida a partir do que o produtor e receptor tomam por verdadeiro.” (LIMA, 2000: 64-5)

Ao longo da história, a literatura já “fingiu” ser a voz do passado, a palavra de Deus, o espelho da sociedade, a prova científica, a expressão da alma, a revolução do pensamento, a literatura intentou ser o mundo. O que ela é - entre os extremos da realidade e do mundo paralelo depende do papel concedido à imagem ficcional pelo homem. Mas o que ela pode ser - fonte de conhecimento ou entretenimento barato - é uma potência da mímesis que nunca é suficientemente avaliada.

\section{Referências}

ARISTÓTELES. Poética. São Paulo: Nova Cultural, 1991.

AUERBACH, E. Mimesis: a representação da realidade na literatura ocidental. São Paulo: Perspectiva, 1994.

AUMONT, J. A imagem. Campinas: Papirus, 1995.

FORTINI, F. Literatura. In: ENCICLOPÉDIA Einaudi. vol 17. Lisboa: Imprensa Nacional/Casa da Moeda, 1989. p. 176-199.

FOUCAULT, M. Linguagem e Literatura. In: MACHADO, R. Foucault, a filosofia e a literatura. Rio de Janeiro: Jorge Zahar, 2000.

GÓRGIAS. Testemunhos e fragmentos. Lisboa: Colibri, 1993.

HAVELOCK, E. Prefácio a Platão. São Paulo: Papirus, 1996.

LIMA, L. C. Mímesis: desafio ao pensamento. Rio de Janeiro: Civilização Brasileira, 2000.

PLATÃO. A República. São Paulo: Martins Fontes, 2006.

. Sofista. São Paulo: Nova Cultural, 1991.

SOUZA, R. A. de. Iniciação aos Estudos Literários. São Paulo: Martins Fontes, 2006.

VERNANT, J. P. Mito e pensamento entre os Gregos. São Paulo: Difel, 1973. 